\title{
Hemşirelerin Bireysel Yenilikçilik Davranışları ve Bu Davranışları Etkileyen Faktörlerin İncelenmesi
}

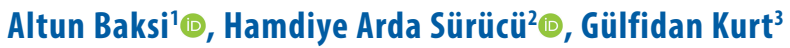

'Süleyman Demirel Üniversitesi Sağlık Bilimleri Fakültesi, Hemşirelik Bölümü, Doğu Kampüsü, Çünür, Isparta, Türkiye

2Dicle Üniversitesi, Atatürk sağlık Yüksek Okulu, Hemşirelik Bölümü, Diyarbakır, Türkiye ${ }^{3}$ Ankara Şehir Hastanesi Kadın Doğum Hastanesi, Pastpartum Servisi, Ankara, Türkiye

Altun Baksi, Dr. Öğr. Üyesi Hamdiye Arda Sürücü, Doç. Dr. Gülfidan Kurt, Hemşire

İletişim:

Doç. Dr. Hamdiye Arda Sürücü

Dicle Üniversitesi, Atatürk sağlık Yüksek Okulu, Hemşirelik Bölümü, Diyarbakır, Türkiye Tel: +905056175386

E-Posta:har_da@hotmail.com
ÖZET

Amaç: Hemşirelerin bireysel yenilikçilik davranışlarının ve etkileyen faktörlerin incelenmesidir.

Gereç Yöntem: Araştırma tanımlayııı tiptedir. Araştırma, Türkiye'nin doğusunda yer alan bir ilin devlet hastanesinde çalışan hemşirelerde Nisan-Haziran 2018 tarihlerinde yürütülmüştür. Araştırmanın örneklemini yoğun bakım kliniklerinde (n: 55) ve dahili/cerrahi kliniklerde ( $\mathrm{n}$ : 95) çalışan toplam 150 hemşire oluşturmuştur. Araştırma için ölçeğin uyarlamasını yapan yazarlardan, kurumdan ve hemşirelerden izin alınmıştır. Veriler sayı, yüzde, ortalama, bağımsız gruplarda student $t$ testi, Kruskall Wallis ve Pearson korelasyon analizi ile değerlendirilmiştir.

Bulgular: Araştırmaya katılan hemşirelerin yaş ortalaması $28,42 \pm 6,18, \% 70^{\prime}$ i kadın ve $\% 57,3^{\prime}$ í lisans mezunudur. Hemşirelerin bireysel yenilikçilik toplam ölçek puanı 70,71 $\pm 9,79$ bulunmuştur. Hemşirelerin bireysel yenilikçiliklerini etkileyen faktörlere bakıı lı̆ında; cinsiyet, medeni durum, eğitim durumu, ekonomik durum, mesleki deneyim, çalışllan klinik, kliniğin iş yoğunluğu, haftalık çalışma saati, mesleki etkinliklere katılma durumu ve yaş gibi değişkenlerin etkilemediği bulunmuştur $(p>0,05)$. Bununla birlikte mesleği sevme durumu ve meslek ile ilgili araştırma faaliyetlerine katılma durumunun bireysel yenilikçiliği etkilediği saptanmıştır $(p<0,05)$.

Sonuç: Hemşirelerin genel olarak yenilikçilik puanlarına bakıldığında sorgulayııı grupta oldukları görülmektedir. Hemşirelerin mesleği sevme ve meslek ile ilgili araştırmalara katııım durumlarının bireysel yenilikçiliği etkilediği saptanmıştır. Bu doğrultuda hemşirelerin araştırmalara ve diğer etkinliklere katılım konusunda motive edilmesi, fırsat verilmesi, yeterli zaman ve kaynak sağlanması önerilmektedir.

Anahtar sözcïkler: Bireysel yenilikçilik, inovasyon, hemşire, hemşirelik

INDIVIDUAL INNOVATION BEHAVIOR OF NURSES AND INVESTIGATION OF FACTORS AFFECTING THESE BEHAVIORS

\section{ABSTRACT}

Objective: To examine the individual innovation behaviors and influencing factors of nurses.

Materials and Methods: This descriptive study was conducted in a state hospital, located in a province in eastern Turkey on nurses working there from April to June 2018. The sample of the study consisted of 150 nurses working in intensive care clinics (n: 55) and medical/surgical clinics ( $n$ : 95). Permission was taken from the authors who conducted the adaptation of the scales, institutions and nurses. Data were evaluated by number, percentage, mean, independent t-test, Kruskal-Wallis and Pearson correlation analysis.

Results: The mean age of the nurses participating in thestudy was $28.42 \pm 6.18,70 \%$ were women and $57.3 \%$ were undergraduate. The total scale score of the individual innovation of the nurses was $70.71 \pm 9.79$. Considering the factors affecting the individual innovation of nurses; gender, marital status, educational status, economic status, occupational experience, the workload of the clinic, weekly working hours, participation in professional activities and age were not affected ( $p>0.05)$. However, participation in professional research and love of the profession variables have been found to affect individual innovation $(p<0.05)$.

Conclusion: It is observed that nurses are in the "early majority" group when we look at the innovation scores in general. It was determined that nurses' participation in professional research and love of profession variables affected individual innovation. In this respect, it is recommended that nurses are encouraged to participate in research and other activities, giving opportunities and providing sufficient time and resources.

Keywords: Individual innovation, innovation, nurse, nursing 
G ünümüzde bilimsel bilginin önemi artmakta ve sağlık bakım uygulamaları hızla değişmektedir (1). Değişim ile birlikte toplumun farklılaşan beklenti ve ihtiyaçlarını karşılayabilmek ve yüksek kalitede sağlık hizmeti sunabilmek için kurumların, yöneticilerin ve çaIışanların kendilerini sürekli yenilemesi ve yenilikçiliği bir davranış haline getirmesi gerekmektedir $(2,3)$. Yenilikçilik (inovasyon), yeni ve değerli bir bilgiyi ya da fikri, ürün, süreç veya hizmet olarak doğru zamanda somutlaştırmak ve toplumsal faydaya dönüştürmektir $(2,4)$. Kavram olarak, hem bir süreci (yenileme/yenilenme) hem de bir sonucu (yenilik) içeren inovasyon, sosyal, ekonomik ve bilimsel olarak başarılı olmanın ve ilerlemenin tek yoludur $(1,2,5)$. Yenilikçiliğin toplumun yaşam kalitesini yükseltmek (1) ve sağlık sisteminin ilerleyebilmesi için en önemli araç olduğu belirtilmektedir (6).

Uluslararası Hemşireler Birliği (International Council of Nurses=ICN) yenilikçiliği "yeni yaklaşımlar, teknolojiler ve çalışma yolları geliştirme süreci" olarak tanımlamaktadır (4). Literatürde hemşirelikte yenilikçi davranışı geliştirmenin sağlığın sürdürülmesi ve daha iyi bir hale getirilmesi, hastalıkların önlenmesi, hasta bakımının daha iyi sunulabilmesi ve sağlık bakım maliyetinin azaltılması açısından önemli olduğu belirtilmektedir $(4,5)$. Son yıllarda kaynakların sınırlı olması, sürekli ve hızlı değişim, bilginin artması ve küresel işgücü eksikliği nedeniyle hemşirelere daha yenilikçi olmaları konusunda çağrı yapılmaktadır $(1,7)$. Hemşireler bilimsel temelli karmaşık hizmet sisteminde neyin önemli olduğunu bilerek daha uygun, daha etkili ve daha ekonomik olup olmadığını sorgulayarak hizmetlerini sürekli revizyona götürmelidir (1). Yenilikçilik açısından bireyler sahip oldukları özelliklere göre beş farklı gruba ayrılmaktadır. Bu gruplar, baskın özellikleri bakımından yenilikçiler, öncüler, sorgulayıcılar, kuşkucular ve gelenekçiler olarak isimlendirilmektedir $(2,8,9)$. Literatürde en iyi yenilikçilerin sistematik bir şekilde yeni bilgiyi üretmek için eski bilgileri hammadde olarak kullandıkları ve sürekli gelecek vaat eden fikirleri aradıkları belirtilmektedir (10). Bireysel yenilikçilik risk alma, deneyime açık olma ve fikir önderliği gibi kavramları içermektedir. Bireysel yenilikçiliğin ön koşulu olarak; yeterli düzeyde eğitime sahip olma, ilgili alanlarda deneyimli olma, yaratıcı düşünme becerisine sahip olma, problemi benimseme ve çözümü için motive olmak gerektiği belirtilmektedir (11).

Literatürde hemşirelerin bireysel yenilikçilik davranışları ve etkileyen faktörler ile ilgili sınırlı sayıda araştırma olduğu görülmektedir. Hemşirelerin yenilikçi davranışları ve etkileyen faktörlere yönelik olarak yapılan niteliksel bir çalışmada; hemşirelerin genellikle başkaları tarafından geliştirilen yeniliği uyguladıkları, yenilik sürecinde meslektaşlarını ve yöneticisini etkilemeye ve ikna etmeye çalıştıkları, risk alma ve tartışmadan uzak durdukları saptanmıştır. Hemşirelerin yenilikçi davranışlarını etkileyen faktörler arasında mesleki, bireysel, organizasyonel ve çevresel faktörler yer almaktadır (12). Hemşirelerin yenilikçi davranışlarının ve etkileyen faktörlerin incelendiği bir araştırmada orta düzeyde yenilikçi oldukları ve yenilikçilik davranışlarının uzmanlık sertifikasının olması, roller, eğitim düzeyi, hastanenin büyüklüğü ve hastanenin yenilikçilik düzeyinden etkilendiği belirlenmiştir (13). Literatürde inovasyona yönelik en önemli beş engel arasında; kısa vadeli eylemlere odaklanma, zaman, kaynak ve personel eksikliği, sistematik bir yenilik sürecinin olmaması ve yönetimsel olarak inovasyonu teşvik etmeye yönelik bir yapılandırımanın olmaması yer almaktadır (10). Hemşirelik hizmet kalitesini doğrudan etkileyen temel faktörler arasında yenilikçi stratejilerin sunulması ve kullanımının değerlendirilmesi yer almaktadır (1). Bu doğrultuda araştırmanın amacı; hemşirelerin bireysel yenilikçilik davranışlarının ve etkileyen faktörlerin incelenmesidir.

\section{Gereç ve yöntem}

Araştırmanın tipi

Araştırma tanımlayıcı tiptedir.

Araştırmanın yeri ve zamanı

Araştırma, Türkiye'nin doğusunda yer alan bir ilin devlet hastanesinde çalışan hemşirelerde Nisan-Haziran 2018 tarihlerinde yürütülmüştür.

\section{Araştırmanın örneklemi}

Araştırmanın örneklemini; araştırmaya gönüllü olarak katılmayı kabul eden dahili/cerrahi ( $\mathrm{n}$ : 95) ve yoğun bakım (n: 55) kliniklerinde çalışan toplam 150 hemşire oluşturmuş̧tur.

\section{Veri toplama araçları}

Araştırma verileri; araştırmacılar tarafından literatür doğrultusunda hazırlanan "Tanıtıcı Bilgiler Formu" ve "Bireysel Yenilikçilik Ölçeği" kullanılarak toplanmıştır.

\section{Tanıtıcı bilgiler formu}

Tanıtıcı bilgiler formu; sosyo-demografik ve meslek/çalışma durumları ile ilgili tanımlayıcı özellikler ile ilgili toplam 13 sorudan "yaş, cinsiyet, medeni durum, eğitim durumu, ekonomik durumu, meslekte deneyim yılı, çalışılan klinik, çalıştı̆̆ı kliniğin yoğunluk derecesi, haftalık çalışma saati, yoğun bakımda deneyim yılı, mesleğini sevme durumu, mesleği ile ilgili etkinliklere katılım, mesleği ile ilgili araştırma faaliyetlerine katılma durumu" oluşmaktadır $(3,12,13)$. 
Bireysel yenilikçilik ölçeği

Ölçek, Hurt ve ark. tarafından 1977 yılında öğretmenler ve üniversite öğrencileri üzerinde bireysel olarak yenilikçilik durumunu değerlendirebilmek amacıyla geliştirilmiştir. Ölçek, hemşirelerin bireysel olarak yenilikçilik durumunu değerlendirebilmek amacıyla Kemer ve Altuntaş tarafından 2017 yılında Türkçeye uyarlanmıştır. Özgün ölçek, 20 madde ve iç tutarlılık güvenilirlik katsayısı toplam ölçek için 0,89 dur. Ölçeğin Türkçeye uyarlanmış hali 18 madde ve üç alt boyuttan "fikir önderliği, değişime direnç, risk alma" oluşmaktadır. Ölçek beşli likert tipi "Kesinlikle Katılmıyorum: 1, Katılmıyorum: 2, Kararsızım: 3, Katılıyorum: 4, Kesinlikle Katılıyorum:5)" bir ölçektir. Ölçeğin madde toplam puan korelasyon değerleri 0,41 ile 0,62 ve faktör yükleri 0,49 ile 0,75 arasındadır. Ölçeğin iç tutarlııı güvenilirlik katsayısı toplam ölçek için 0,82 , alt boyutlar için 0,72 ve 0,80 arasındadır. Ölçeğin 11 maddesi pozitif $(1,2,3,4,7,8,10,11,14,16$, 17), yedi maddesi $(18,15,13,12,9,6,5)$ negatiftir. Uyarlama çalışmasıyla geliştirilen hesaplama yönteminde; negatif maddeler ters puanlanmaktadır. Ölçek alt boyut ve toplam puan değerleri her maddeden alınan puanların toplanmasıyla elde edilmektedir. Ölçekten toplam olarak en az 18 en fazla 90 puan alınmaktadır. Ölçekte bireyler sahip oldukları özellikler bakımından beş farklı kategoriye ayrılmaktadır. Bireylerin aldıkları puanlara göre; 82 ve üstü puan alanların "yenilikçi", 75-82 arasında puan alanların "öncü", 66-74 arasında puan alanların "sorgulayıcı", 58-65 arasında puan alanların "kuşkucu" ve son olarak 57 ve altında alanların "gelenekçi" kategoride olduğu belirlenmiştir (11).

\section{Verilerin toplanması}

Araştırma verileri; hemşirelere araştırma ile ilgili bilgi verildikten sonra araştırmaya katılmayı kabul edenler ile uygun bir ortamda yüz-yüze görüşme yöntemi kullanılarak toplanmıştır.

\section{Verilerin değerlendirilmesi}

Araştırma verilerinin değerlendirilmesi bilgisayar ortamında SPSS 16,0 (Statistical Package for the Social Sciences) istatistiksel yazılım programı kullanılarak gerçekleştirilmiştir. Araştırma verilerinin sunumunda sayı, yüzde, ortalama ve minumum-maksimum gibi tanımlayıcı istatistikler kullanılmıştır. Araştırmada hemşirelerin sosyo-demografik ve çalışma özelliklerine göre bireysel yenilikçilik düzeylerinin incelenmesi için bağımsız gruplarda student $t$ testi, Kruskall Wallis ve Pearson korelasyon analizi uygulanmıştır. Hemşirelerin mesleği sevme durumu ile bireysel yenilikçilik puan ortalaması arasında anlamlı ilişki tespit edilmiştir. Bireysel yenilikçilik ve mesleği sevme arasındaki anlamlı ilişkinin mesleği sevme boyutunda hangi kategoriden kaynaklandığının belirlenmesi için ileri analiz yapılmıştır.
Araştırmanın etiği

Araştırmanın yürütüldüğü kurumdan ve ölçeğin kullanılabilmesi için uyarlamasını yapan yazarlardan yazılı izin alınmıştır. Araştırmaya katılmayı kabul eden kişilerden sözel izin alınmıştır. Kişilerden sözel izin alınırken araştırmanın amacı, uygulanması, verilerin toplanması, araştırmaya katılmanın gönüllülüğe bağlı olduğu ve isimlerinin saklı tutulacağına dair bilgi verilmiştir.

\section{Bulgular}

Araştırmaya katılan hemşirelerin yaş ortalaması 28,42 $\pm 6,18, \% 70$ 'i kadın, \%63,3'ü evli, \%57,3'ü lisans mezunu ve $\% 66$ 'sı ekonomik düzeyini orta olarak değerlendirmektedir. Hemşirelerin $\% 55,3$ 'ünün mesleki deneyimi 1-5 yıl, \%63,3'ü dahili veya cerrahi kliniklerde çalışmakta, $\% 56,7$ 'si kliniğin iş yoğunluğunu "çok" olarak değerlendirmekte ve $\% 60,7$ 'si haftada 40-48 saat arasında çalışmaktadır. Hemşirelerin \%52'sinin mesleğini orta derecede sevdiği, \%58'inin hemşirelik mesleği ile ilgili etkinliklere katılmadığı ve $\% 65,3$ 'ünün hemşirelik mesleği ile ilgili araştırma faaliyetlerine katılmadığı saptanmıştır. Araştırmaya katılan hemşirelerin bireysel yenilikçilik toplam ölçek puanı 70,71 $\pm 9,79$ olarak bulunmuştur (Tablo 1). Hemşirelerin bireysel yenilikçilik puanına göre; $\% 40,7$ 'sinin sorgulayıcı, $\% 23,3$ 'ünün öncü, \%15,3'ünün kuşkucu, \%12,7'sinin yenilikçi ve \%8'inin gelenekçi olduğu belirlenmiştir.

Hemşirelerin bireysel yenilikçilerini etkileyen faktörlere bakıldığında; cinsiyet, medeni durum, eğitim durumu, ekonomik durum, mesleki deneyim yılı, çalışılan klinik, kliniğin iş yoğunluğu, haftalık çalışma saati, mesleki etkinliklere katılma durumu ve yaş gibi değişkenlerin etkilemediği saptanmıştır ( $p>0,05)$. Mesleği sevme durumu ve hemşirelik mesleği ile ilgili faaliyetlere katılma durumu gibi değişkenlerin bireysel yenilikçiliği etkilediği belirlenmiştir $(p<0,05)$. Hemşirelik mesleği ile ilgili araştırma faaliyetlerine katılan hemşirelerin bireysel yenilikçi puan ortalaması istatiksel olarak anlamlı daha yüksek olduğu bulunmuştur. Bunun yanı sıra, hemşirelerin mesleği sevme durumu ile bireysel yenilikçilik arasındaki ilişkiye ileri analiz ile bakıldığında mesleğini az seven hemşirelerin bireysel yenilikçi puanın ortalamasının diğer kategorilere göre istatistiksel olarak anlamlı daha düşük olduğu bulunmuştur $(p<0,05)$ (Tablo 2).

\section{Tartışma}

Bu bölümde hemşirelerin bireysel yenilikçilik davranışları ve etkileyen faktörler tartışıımıştır. Bu konuda sınırlı sayıda araştırma olduğu için farklı örneklem grupları ile yapılan araştırmalara da yer verilmiştir. Araştırmaya katılan 
Tablo 1. Hemşirelerin sosyo-demografik ve tanımlayıcı özelliklerinin incelenmesi

\begin{tabular}{l} 
Değişkenler \\
\hline Cinsiyet \\
Kadın \\
Erkek \\
\hline Medeni Durum \\
Bekar \\
Evli \\
\hline Eğitim Durumu \\
Lise \\
Önlisans \\
Lisans \\
Lisansüstü
\end{tabular}

Ekonomik Durum
Kötü
Orta
liyi

\section{Mesleki deneyim yılı}

$1-5$ yil

$6-10 \mathrm{yll}$

$11-15$ yıl

16 yıl ve üstü

Sayı

Yüzde

\section{Çalışılan klinik}

Dahili veya cerrahi klinikler

Yoğun bakım

45

70,0

30,0

$55 \quad 36,7$

$95 \quad 63,3$

\section{Kliniğin yoğunluk derecesi}

\begin{tabular}{lcc} 
Orta & 65 & 43,3 \\
Çok & 85 & 56,7 \\
\hline Haftalık çalışma saati & & \\
40 altı & 24 & 16,0 \\
$40-48$ saat & 91 & 60,7 \\
48 saat üstü & 35 & 23,3 \\
\hline Mesleği sevme durumu & & \\
Hiç sevmiyorum & 12 & 8,0 \\
Az seviyorum & 26 & 17,3 \\
Orta derecede seviyorum & 78 & 52,0 \\
Çok seviyorum & 34 & 22,7
\end{tabular}

Hemşirelik mesleği ile ilgili

etkinliklere (kongre, sempozyum vs)

katılma durumu

$\begin{array}{lll}\text { Evet } & 63 & 42,0 \\ \text { Hayır } & 87 & 58,0\end{array}$

Hemşirelik mesleği ile ilgili araştırma faaliyetlerine katıma durumu

\begin{tabular}{lll} 
Evet & 52 & 34,7 \\
Hayır & 98 & 65,3 \\
\hline
\end{tabular}

\begin{tabular}{lcc}
\hline & $\begin{array}{c}\text { Ortalama } \\
\text { (standart } \\
\text { sapma) }\end{array}$ & $\begin{array}{c}\text { Minimum- } \\
\text { maksimum }\end{array}$ \\
\hline Yaş & $28,42 \pm 6,18$ & min-max $=18,00-49,00$ \\
\hline $\begin{array}{l}\text { Bireysel yenilikçilik ölçeği } \\
\text { toplam puanı }\end{array}$ & $70,71 \pm 9,79$ & min-max $=38,00-88,00$ \\
\hline $\begin{array}{l}\text { Bireysel yenilikçilik ölçeği } \\
\text { alt boyut toplam puanı }\end{array}$ & & \\
$\begin{array}{l}\text { Fikir önderliği } \\
\text { Değişime direnç }\end{array}$ & $25,85 \pm 4,77$ & min-max $=14,00-35,00$ \\
Risk alma & $18,57 \pm 5,81$ & min-max $=7,00-35,00$ \\
& $15,93 \pm 3,18$ & min-max $=6,00-20,00$
\end{tabular}

Tablo 2. Hemşirelerin sosyo-demografik ve çalışma özelliklerine göre bireysel yenilikçilik düzeylerinin incelenmesi

Değişkenler

Ortalama Test, $p$ değeri

\begin{tabular}{lcc}
\hline $\begin{array}{l}\text { Cinsiyet } \\
\text { Kadın }\end{array}$ & $\begin{array}{c}70,66 \pm 10,19 \\
\text { Erkek }\end{array}$ & $\begin{array}{c}* t=-.089, \\
\mathrm{p}=0,929\end{array}$ \\
\hline Medeni durum & & \\
Bekar & $69,49 \pm 9,80$ & $\mathrm{t}=-1,165$, \\
Evli & $71,42 \pm 9,76$ & $\mathrm{p}=0,246$ \\
\hline Eğitim durumu & & \\
Lise & $69,33 \pm 5,10$ & \\
Önlisans & $68,93 \pm 8,33$ & $* * \mathrm{KW}=6,041$, \\
Lisans & $72,29 \pm 10,09$ & $\mathrm{p}=0,110$ \\
Lisansüstü & $65,14 \pm 16,72$ & \\
\hline
\end{tabular}

\section{Ekonomik durum}

$\begin{array}{lcc}\text { Kötü } & 71,25 \pm 10,95 & \mathrm{KW}=.743, \\ \text { Orta } & 70,25 \pm 9,52 & \mathrm{p}=0,690 \\ \text { Iyi } & 71,67 \pm 10,34 & \end{array}$

\section{Mesleki deneyim yılı}

\begin{tabular}{|c|c|c|}
\hline $\begin{array}{l}1-5 \text { yll } \\
6-10 \text { yll } \\
11-15 \text { yll } \\
16 \text { yıl ve üstü }\end{array}$ & $\begin{array}{c}69,83 \pm 8,75 \\
70,00 \pm 11,76 \\
73,12 \pm 10,70 \\
75,91 \pm 6,90\end{array}$ & $\begin{array}{c}\mathrm{KW}=5,693, \\
\mathrm{p}=0,128\end{array}$ \\
\hline \multicolumn{3}{|l|}{ Çalışılan klinik } \\
\hline Dahili veya cerrahi klinikler & $70,63 \pm 9,30$ & $t=-.134$ \\
\hline Yoğun bakım & $70,85 \pm 10,66$ & $p=0,894$ \\
\hline \multicolumn{3}{|l|}{ Kliniğin yoğunluk derecesi } \\
\hline Orta & $69,20 \pm 7,76$ & $t=-1,665$ \\
\hline Çok & $71,87 \pm 10,99$ & $p=0,098$ \\
\hline \multicolumn{3}{|l|}{ Haftalık çalısma saati } \\
\hline 40 altı & $67,91 \pm 7,22$ & \\
\hline 40-48 saat & $71,39 \pm 9,62$ & $\mathrm{KW}=4,903$, \\
\hline 48 saat üstü & $70,85 \pm 11,52$ & $p=0,086$ \\
\hline \multicolumn{3}{|l|}{ Mesleğini sevme durumu } \\
\hline Hiç sevmiyorum & $72,91 \pm 9,12$ & \\
\hline Az seviyorum & $62,61 \pm 9,23$ & \\
\hline Orta derecede seviyorum & $71,76 \pm 7,59$ & $k W=25,323$, \\
\hline Çok seviyorum & $73,70 \pm 11,86$ & \\
\hline
\end{tabular}

$\begin{array}{lll}\begin{array}{l}\text { Hemşirelik mesleği ile ilgili } \\ \text { etkinliklere (kongre, sempozyum vs) } \\ \text { katılma durumu }\end{array} & & \\ \begin{array}{lll}\text { Evet } & & \\ \text { Hayır } & 72,31 \pm 1,26 & \mathrm{t}=1,719, \\ & 69,55 \pm 9,51 & \mathrm{p}=0,088 \\ \hline\end{array}\end{array}$

Hemşirelik mesleği ile ilgili araştırma faaliyetlerine katılma durumu

\begin{tabular}{|c|c|c|}
\hline $\begin{array}{l}\text { Evet } \\
\text { Hayır }\end{array}$ & $\begin{array}{l}74,57 \pm 9,92 \\
68,66 \pm 9,12\end{array}$ & $\begin{array}{l}t=3,664, \\
p<0,001\end{array}$ \\
\hline & $r$ & $p$ \\
\hline Yaş & 0,119 & 0,146 \\
\hline
\end{tabular}

*t, Bağımsız gruplarda student $t$ testi.

**KW, Kruskal Wallis Test 
hemşirelerin bireysel yenilikçilik puanlarının orta düzeyde $(70,71 \pm 9,79)$ olduğu saptanmıştır. Bireysel yenilikçilik alt boyut puan ortalamalarına bakıldığında fikir önderliğinin en yüksek, değişime direnç puan ortalamasının ise en düşük olduğu görülmektedir. Hemşirelerin yenilikçilik davranışlarının incelendiği farklı bir ölçek kullanılarak yapılan bir araştırmada yenilikçilik puan ortalamalarının orta düzeyde olduğu belirtilmiştir (13). Yine yenilikçilik puanları açısından hemşirelik öğrencileri ve öğretmen adayları gibi farklı gruplar ile yapılan çalışmalar ile araştırma bulguları benzerlik göstermektedir $(3,14,15)$. Hemşirelerin bireysel yenilikçilik puanına göre; \%40,7'sinin sorgulayıcı ve $\% 12,7$ 'sinin yenilikçi olduğu saptanmıştır. Hemşirelerin genel olarak bireysel yenilikçilik puanlarına göre sorgulayıc grupta olduğu saptanmış ve bu bulgu literatürle benzerlik göstermektedir $(8,14,16-19)$. Literatürde sorgulayıcıların toplum içerisinde yenilik açısından fikir sahibi pozisyonunda olmalarına rağmen yeni fikirleri uygulama konusunda nadiren liderlik yaptıkları, yeniliklere karşı temkinli davrandıkları ve yenilikleri benimsemeden önce büyük bir zamanı onun hakkında düşünmeyle geçirdikleri belirtilmektedir (2). Araştırma örnekleminde yer alan hemşirelerin bireysel yenilikçilik puanları açısından genel olarak sorgulayıc grupta olması ve yarıya yakınının sorgulayıcı olduğu göz önüne alındığında örneklemde yer alan hemşirelerin sorgulayıcıların genel özelliklerini taşıdığı ve bu doğrultuda yenilikçi davranışların geliştirilmesi gerektiği söylenebilir.

Araştırmada yer alan hemşirelerin bireysel yenilikçiliklerini etkileyen faktörlere bakıldığında; mesleğini az seven hemşirelerin bireysel yenilikçilik puan ortalamalarının daha düşük ve araştırmalara katılan hemşirelerin puan ortalamalarının daha yüksek olduğu saptanmıştır. Literatürde bireysel ve mesleki faktörlerin yenilikçi davranışları etkilediği belirtilmektedir $(12,20)$. Literatürde bireysel faktörler arasında bireyin yenilikçi iş davranışlarına katılımı için istekli (örn. motive, memnun) olması gerektiği belirtilmektedir (20). Mesleğini az seven hemşirelerin yenilikçilik puan ortalamalarının daha düşük olması; meslek ile ilgili sorunlara ve çözümüne daha az motive olarak yenilikçi davranışları daha az göstermeleri ile ilgili olabilir. Fakat araştırma bulgularında mesleğini hiç sevmeyen hemşirelerin bireysel yenilikçilik puan ortalaması açısından farklılık göstermemesi alınan örneklem grubunun özellikleri ile ilgili olduğunu düşündürmektedir. Araştırma faaliyeti, yenileşim sürecinde yer alan hemşirelerin yenilikçi davranışlarından birisidir (6). Literatürde araştırma faaliyetlerine katılmanın yenilikçi düşünce ve uygulama becerilerini geliştirdiği belirtilmektedir (21). Hemşireler üzerinde yapılan niteliksel bir araştırmada araştırmacı olmanın yenilikçiliği etkileyen bireysel faktörlerden birisi olduğu belirtilmiştir (12). Hemşirelik öğrencileri üzerinde yapılan bir araştırmada bakımda yenilikleri takip eden öğrencilerin bireysel yenilikçilik davranış ortalamalarının daha yüksek olduğu saptanmıştır (3). Bu doğrultuda araştırma örnekleminde araştırmalara katılan hemşirelerin yenilikçilik puan ortalamalarının daha yüksek olması araştırma faaliyetlerine katılmanın yenilikçi davranış becerilerini geliştirmiş olmaları ile ilgili olduğu düşünülmektedir.

Araştırmada yer alan hemşirelerin bireysel yenilikçilik davranışlarını; cinsiyet, medeni durum, eğitim durumu, ekonomik durum, mesleki deneyim yılı, çalışılan klinik, kliniğin iş yoğunluğu, haftalık çalışma saati, mesleki etkinliklere katılma durumu ve yaş gibi değişkenlerin etkilemediği saptanmıştır $(p>0,05)$. Hemşirelerin yenilikçilik davranışları ve etkileyen faktörlerin incelendiği bir araştırmada; cinsiyet, çalışılan klinik (kritik bakım alanları ve diğerleri) ve çalışma şeklinin bireysel yenilikçilik davranışını etkilemediği; lisansüstü eğitim düzeyinin yenilikçilik davranışını arttırdığı saptanmıştır (13). Araştırma bulgularında bireysel yenilikçilik davranışının çalışılan kliniğe (dahili/cerrahi ve yoğun bakım kliniklerinde) ve klinik iş yoğunluğuna göre (orta ve çok) değişmediği saptanmıştır. Literatürde yoğun bakım bilgi ve uygulamaları, bilim ve teknolojideki gelişmelere paralel olarak her geçen gün hızla değiştiği için yoğun bakım hemşiresinin yenilikleri yakından takip etmesi gerektiği belirtilmektedir (22). Literatürde rutin olmayan, karmaşık bir işin yenileşim için pozitif etkili, iş yükü fazlalığının ise negatif etkili olduğu, bu nedenle dengenin sağlanması gerektiği belirtilmektedir (20). Hemşireler üzerinde yapılan niteliksel bir çalışmada iş yükü fazlalığının yenilikçi davranışı negatif yönde etkileyebileceği belirtilmiştir (12). Bu durum yoğun bakım hemşirelerinin iş yükü fazlalığı, klinik iş yoğunluğu az olan hemşire grubu olmaması, haftalık çalışma saatlerinin birbirine yakın olması ile ilgili olabilir. Baş hemşirelerin yenilikçilik davranışlarını etkileyen faktörlerin incelendiği bir araştırmada yaş, medeni durum, eğitim düzeyi ve meslekte deneyim yılının etkilemediği saptanmıştır (23). Baş hemşireler üzerinde yapılan başka bir araştırmada lisansüstü eğitim düzeyinin yenilikçiliği etkilediği belirlenmiştir (24). Farklı bir örneklem olarak öğretmenler üzerinde yapılan bir araştırmada cinsiyet ve kıdemin bireysel yenilikçiliği etkilemediği saptanmıştır (25). Genel olarak bu araştırma bulguları literatür ile benzerlik göstermektedir. Eğitim düzeyi açısından bakıldığında farklı bulgular olduğu görülmektedir. Literatürde eğitim, işine ilişsin bilgi ve uzmanlığın yeni fikirlere açık olmayı ve özgüveni sağlayarak yenilikçi davranışı etkilediği belirtilmektedir $(12,13,20)$. Araştırma örnekleminde yer alan hemşirelerde eğitim düzeyinin yenilikçiliği etkilememesi 
lisansüstü eğitim gören hemşirelerin sayısının az olması ya da grubun özellikleri ile ilgili olabilir.

\section{Sonuç}

Bu bulgular doğrultusunda hemşirelerin orta düzeyde yenilikçi oldukları ve genel olarak bakıldığında yenilikçilik puanları açısından sorgulayıcı grupta oldukları görülmektedir. Literatürde sorgulayıcıların yeni fikirleri benimsemeden önce uzun zaman düşündükleri ve uygulama konusunda nadiren liderlik yaptıkları belirtilmektedir. Hemşirelerin meslek ile ilgili araştırmalara katılma ve mesleği sevme durumu gibi değişkenlerin bireysel yenilikçiliği etkilediği saptanmıştır. Fakat cinsiyet, medeni durum,

\section{Kaynaklar}

1. Kara Yilmaz D. Innovation in nursing practices. Global Journal on Advances in Pure \& Applied Sciences 2015;7:170-4. [CrossRef]

2. Sarıoğlu A. Bireysel yenilikçilik ölçeğinin hemşirelikte geçerlik ve güvenirliği. Atatürk Üniversitesi: Sağlık Bilimleri Enstitüsü, Yüksek Lisans Tezi. Erzurum, 2014.

3. Tarhan M, Doğan P. Hemşirelik öğrencilerinin bireysel yenilikçilik davranışları ile otonomi düzeyleri arasındaki ilişki. Sağlık Bilimleri ve Meslekleri Derg 2017;5:51-8.

4. International Council of Nurses. Delivering quality, serving communities: Nurses leading care innovations. International Council of Nurses, Switzerland, 2009.

5. Kartal H, Kantek F. Hemşirelikte İnovasyon Örnekleri. Sağlık ve Hemşirelik Yönetimi Derg 2018;5:57-63. [CrossRef]

6. Joseph ML. Organizational culture and climate for promoting innovativeness. J Nurs Admin 2015;45:172-8. [CrossRef]

7. Herdman EA. (Çeviri Korkmaz ÖY). Hemşirelik ve yenilikçilik. HEAD 2009;6:2-4. https://www.journalagent.com/kuhead/pdfs/ KUHEAD_6_2_2_4.pdf

8. Korucu AT, Olpak YZ. Öğretmen adaylarının bireysel yenilikçilik özelliklerinin farklı değişkenler açısından incelenmesi. Eğitim Teknolojisi Kuram ve Uygulama 2015;5:111-27. https://dergipark. org.tr/tr/download/article-file/71848

9. Kılıçer K, Odabaşı HF. Bireysel yenilikçilik ölçeği (BYÖ): Türkçeye uyarlama, geçerlik ve güvenirlik çalışması. Hacettepe Üniversitesi Eğitim Fakültesi Derg 2010;38:150-64. https://dergipark.org.tr/tr/ download/article-file/87448

10. Hughes F. Nurses at the forefront of innovation. Int Nurs Rev 2006;53:94-101. [CrossRef]

11. Satıoğlu Kemer A, Altuntaş S. Bireysel yenilikçilik ölçeği'nin hemşireliğe uyarlanması: Türkçe geçerlik - güvenirlik çalışması. HEAD 2017;14:52-61. [CrossRef]

12. Sönmez B, Yıldırım A. Bir üniversite hastanesinde çalışan hemşirelerin yenilikçi davranışları ve yenilikçi davranışlarını etkileyen faktörlere ilişkin görüşlerinin belirlenmesi: niteliksel bir çalışma. Sağlık ve Hemşirelik Yönetimi Derg 2014;2:49-59. [CrossRef]

13. Dy Bunplin JJ, Chapman S, Blegen M, Spetz J. Differences in innovative behavior among hospital-based registered nurses. J Nurs Adm 2016;46:122-7. [CrossRef] eğitim durumu, ekonomik durum, mesleki deneyim yılı, çalışılan klinik, kliniğin iş yoğunluğu, haftalık çalışma saati, mesleki etkinliklere katılma durumu ve yaş gibi değişkenlerin bireysel yenilikçiliği etkilemediği saptanmıştır. Bu doğrultuda hemşirelerin yenilikçi davranışlarının geliştirilebilmesi için hemşirelerin araştırmalara ve diğer etkinliklere katılım konusunda motive edilmesi, fırsat verilmesi, yeterli zaman ve kaynak sağlanması önerilmektedir. Hemşirelerde bireysel yenilikçilik davranışını daha iyi anlayabilmek ve uygun planlamalar yapabilmek adına yenilikçiliği etkileyebilecek değişkenler ve yenilikçi davranışların hasta sonuçlarına yansıması ile ilgili daha fazla araştırma yapılmasına gereksinim bulunmaktadır.

14. Özgür H. Bilişim teknolojileri öğretmen adaylarının eleştirel düşünme eğilimleri ile bireysel yenilikçilik özellikleri arasındaki ilişkinin çeşitli değişkenler açısından incelenmesi. Mersin Üniversitesi Eğitim Fakültesi Derg 2013;9:409-20. http://www.acarindex.com/dosyalar/ makale/acarindex-1423908753.pdf

15. Başoğlu $M$, Durmaz Edeer $A$. $X$ ve $Y$ kuşağındaki hemşirelerin ve hemşirelik öğrencilerinin bireysel yenilikçilik farkındalıklarının karşılaştırılması. Gümüşhane Üniversitesi Sağlık Bilimleri Derg 2017;6:77-84. https://dergipark.org.tr/en/download/ article-file/372159

16. Çuhadar Ç, BülbülT, IlgazG. Öğretmen adaylarının bireysel yenilikçilik özellikleri ile teknopedogojik eğitim yeterlilikleri arasındaki ilişki. İlköğretim Online 2013;12:797-807.

17. Yiğit $S$, Aksay K. Comparison between generation $X$ and generation $Y$ in terms of individual innovativeness behavior: the case of Turkish health professionals. Int J Bus Adm 2015;6:106-17. [CrossRef]

18. Ertuğ N, Kaya H. Hemşirelik Öğrencilerinin Bireysel Yenilikçilik Profilleri ve Yenilikçiliğin Önündeki Engellerin İncelenmesi. HEAD 2017;14 3:192-7. [CrossRef]

19. Demiralay R, Bayır EA, Gelibolu MF. Öğrencilerin bireysel yenilikçilik özellikleri ile çevrimiçi öğrenmeye hazır bulunuşlukları ilişkisinin incelenmesi. Eğitim ve Öğretim Araştırmaları Derg 2016;5:161-7.

20. Parzefall $M-R$, Seeck $H$, Leppänen A. Employee innovativeness in organizations: a review of the antecedents. Finn J Bus Econom 2008;2:165-82.

21. $\mathrm{Xu} \mathrm{Z}$, Chen $\mathrm{H}$. Research and practice on basic composition and cultivation pattern of college students' innovative ability. Int Educ Stud 2010;3:51-5. [CrossRef]

22. Kavaklı Ö, Uzun Ş, Arslan F. Yoğun bakım hemşirelerinin profesyonel davranışlarının belirlenmesi. Gülhane Tıp Derg 2009;51:168-73.

23. Taşkın Yılmaz F, Tiryaki Şen H, Demirkaya F. Başhemşirelerin yenilikçilik ve risk alma davranışlarının belirlenmesi. Balıkesir Sağlık Bil Derg 2014;3:147-54. [CrossRef]

24. Clement-O'Brien K, Polit DF, Fitzpatrick JJ. Innovativeness of nurse leaders. J Nurs Manage 2011;19:431-8. [CrossRef]

25. Kılıç H, Ayvaz Tuncel Z. İlköğretim branş öğretmenlerinin bireysel yenilikçilik düzeyleri ve yaşam boyu öğrenme eğilimleri. Uluslararası Eğitim Programları ve Öğretim Çalışmaları Derg 2014;4:25-37. https://pdfs.semanticscholar.org/debc/7e83e89690166f56a8c44bd a8bb211043d60.pdf 